\title{
Transferring Rights in Freehold Estate through Inheritance based on a Certificate of Heirs in Padang Utara District of Padang City
}

\author{
Ade Kurniawan; Yaswirman; Syofiarti \\ Faculty of Law, University of Andalas, Padang, Indonesia
}

http://dx.doi.org/10.18415/ijmmu.v6i3.878

\begin{abstract}
This study aims to find out how the process of transferring rights in freehold estate through inheritance is based on a certificate of heirs in Padang Utara District, to find out how the legal force of certificate of heirs as a basis for transferring rights in freehold estate through inheritance, and to find out whether the making process of certificate of heirs, as the basis for transferring rights in freehold estate through inheritance, has provided legal certainty related to the heirs listed in the certificate of heirs which are confirmed by the Village Head and District Chief at the testator's residence at the time of his/ her death. This study applies a sociological legal approach; i.e. research that examines applicable legal norms and that relates them to the facts found in research. In addition, it utilizes prescriptive data analysis. The process of transferring rights through inheritance based on a certificate of heirs can be misused by the heirs by not including the names of other legitimate heirs. Thus, the certificate of heirs can be sued by other heirs whose names are not included in the certificate of heirs. In this case, the legal force of certificate of heirs, as the basis for transferring rights in freehold estate through inheritance does not have perfect legal force since the Village Head and District Chief do not have the authority to strengthen the certificate of heirs. Thus, the certificate of heirs does not have legal certainty that is reinforced by the Village Head and District Chief since they do not have legal authority to strengthen the certificate of heirs.
\end{abstract}

Keywords: Transfer of Rights in Freehold Estate; Certificate of Heirs; Inheritance

\section{Introduction}

The existence of population based on race and ethnicity in making certificate of heirs, as the basis for transferring rights through inheritance, can lead to discrimination against Indonesian citizens in terms of equality in law. As stated in Article 27 paragraph (1) of the 1945 Constitution, it states that every citizen has the same position in law and government and is obliged to uphold the law and government without exception. Article $28 \mathrm{D}$ paragraph (1) of the 1945 Constitution states that everyone has the right to recognition, guarantee, protection and fair legal certainty and equal treatment before the law. In addition, Article 5 letters a and b of Law No. 40 of 2008 concerning the Elimination of Racial and Ethnic Discrimination states that the elimination of racial and ethnic discrimination must be carried out by giving: 
1. Protection, certainty, and equal position in the law for every citizen to live free from racial and ethnic discrimination;

2. Guarantee that there will be no barriers to the initiative of individuals, groups of people, or institutions that require protection and guarantee of the equal use of rights as citizens.

3.

Indonesia has enacted various civil laws including European (Western) Civil Law, Foreign East Civil Law, and Customary Civil Law (Customary Law). All of them are officially valid for the population groups in Indonesia. ${ }^{1}$ Plurality of civil law in Indonesia also affects the authority in making certificate of heirs as known in Article 42 of Government Regulation No. 24 of 1997 concerning Land Registration.

Furthermore, Article 111 paragraph (1) letter c Regulation of the Minister of Agrarian Affairs/ Head of the National Land Agency No. 3 of 1997 concerning Implementation Provisions of Government Regulation No. 24 of 1997 concerning Land Registration explains that the letter of proof as heirs can be in the form of: ${ }^{2}$

1. Testament of the testator;

2. Court decision;

3. Decision from the judge/ chairman of the court;

4. For Indonesian citizens (indigenous people), a certificate of heirs is made by heirs witnessed by 2 (two) witnesses and confirmed by the Village Head and District Chief where the testator lived when he/ she passed away;

5. For Indonesian citizens of Chinese descent, a certificate of heirs is made by a notary;

6. For other Indonesian citizens of foreign eastern descent, a certificate of heirs is made by the Heritage Office.

After the establishment of Law No. 3 of 2006 concerning Amendment to Law No. 7 of 1989 concerning the Religious Court, it is determined that for Indonesian citizens who are Muslim, in issuing certificate of heirs, the party authorized to issue a stipulation regarding the distribution of inheritance of a Muslim heir is a Religious Court. ${ }^{3}$ This authority is based on the provisions of Article 49 letter b of Law No. 3 of 2006 concerning Amendment to Law No. 7 of 1989 concerning the Religious Court, which states that the Religious Court has the duty and authority to examine, decide, and settle cases in the first level between people who are Muslim in the inheritance field.

Especially for Indonesian citizens (indigenous people), as stipulated in Article 111 paragraph (1) letter c Regulation of the Minister of Agrarian Affairs/ Head of the National Land Agency No. 3 of 1997 concerning Implementation Provisions of Government Regulation No. 24 of 1997 concerning Land Registration, certificate of heirs made privately by heirs and strengthened by Village Head and District Chief have gaps to be misused because there is no prior research on whether or not the names of the heirs listed in it are correct. For example, an heir who has more than one wife can independently produce information about his inheritance; so, each of them sells the other heirs' assets. ${ }^{4}$ This can lead to disputes between parties because they both have a certificate of heirs and feel most entitled to inheritance from the testator. The participation of the Village Head and District Chief to justify/ witness/ know and sign a private proof of the heir in the form of a certificate of heirs (statement) raises 2 problems which include: (1) Whether or not matters justified/ witnessed/ known by the Village Head and District Chief are they

\footnotetext{
${ }^{1}$ C.S.T., Kansil, 2007, Practice for Exams: Introduction to Indonesian Law, Sinar Grafika, Jakarta, page 18

${ }^{2}$ Gultomlawconsultant.com, Certificate of Heirs and Authorized Parties Who Can Publish it

${ }^{3}$ Ibid

${ }^{4}$ http://Irma devita.com, Description of Inheritance
} 
(legal subjects) whose names and signatures are listed in the certificate of heirs? or (2) Whether or not matters justified/ witnessed/ known by the Village Head and District Chief are the formality (form) of the certificate of heirs (statements) ${ }^{5}$

If matters justified/ witnessed/ known by the Village Head and District Chief are names of the heirs and their signatures, then Village Head and District Chief must know for certain that the names listed in the certificate of heirs are correct as the legitimate heirs. However, it becomes a problem when the Village Head and District Chief are passive and it turns out that the names listed do not include other heirs. In addition, if matters justified/ witnessed/ known by the Village Head and District Chief are the formality of the certificate of heirs, then it is necessary to find out the standard form of a certificate of heirs.

\section{Research Method}

The problem approach method in this study is the sociological legal approach; ${ }^{6}$ i.e. research by reviewing the applicable legal norms and relating them to the facts found in the study. If the law is considered as an empirical social, it is assessed as an independent variable that has an influence and effect on various aspects of social life. ${ }^{7}$ The study is a sociological legal study (socio-legal research). ${ }^{8}$ The data collection used in this study consisted of two techniques which included interviews and document studies. ${ }^{9}$

The process of data analysis begins by examining all available data obtained from library research and field research. All data obtained will be analyzed in such a way that the data is meaningful and useful for answering research problems and questions. ${ }^{10} \mathrm{Next}$, after data analysis is complete, conclusions will be drawn using inductive thinking method; i.e. the mindset that is based on specific things. Then, from these specific matters, a general conclusion is drawn.

\section{Research Results and Discussion}

The Process of Transferring Rights in Freehold Estate through Inheritance Based on a Certificate of Heirs di Padang Utara District of Padang City

In this study, the rights in freehold estate is transferred through inheritance. This transfer of rights in freehold estate through inheritance is regulated in Article 42 paragraph (1) of the Government Regulation of the Republic of Indonesia No. 24 of 1997 concerning Land Registration for registration of the transfer of rights in freehold estate through inheritance regarding land rights that have been registered and rights to apartment units as required according to the provisions referred to in Article 36 which must be submitted by the recipient of rights in land or freehold estate on the apartment unit in question as inheritance to the Land Office, the certificate of rights in question, the death certificate of the person whose name is recorded as the holder of the rights and proof of certificate as heir.

Registration of transferring rights in freehold estate is regulated in Article 111 of the Regulation of the Minister of Agrarian Affairs/ Head of the National Land Agency No. 3 of 1997 with the following conditions:

1. The application for registration of the transfer of rights in freehold estate is submitted by the heir or attorney by attaching:

\footnotetext{
${ }_{6}^{5}$ http://habibadjie.com, Equality in Evidence Making as Heirs

${ }^{6}$ McConville, Mike, ed. Research methods for law. Edinburgh University Press, 2017.

${ }^{7}$ Banakar, Reza, and Max Travers, eds. Theory and method in socio-legal research. Bloomsbury Publishing, 2005.

${ }^{8}$ Amiruddin \& Zainal Asikin, 2004, Introduction to Legal Research Methods, Raja Grafindo Persada, Jakarta, page 133

${ }^{9}$ Webley, Lisa. "Qualitative approaches to empirical legal research." The Oxford handbook of empirical legal research(2010): 926-950.

${ }^{10}$ Chynoweth, Paul. "Legal research." Advanced research methods in the built environment (2008): 28-38.
} 
a. Certificate of rights in freehold estate or certificate of rights in unit of apartment on behalf of the testator or (regarding land that has not yet been registered) proof of ownership as referred to in Article 24 of Government Regulation No. 24 of 1997.

b. Letter of death on behalf of the rights holders listed in the certificate from the Head of the Village where the testator lived when he/ she passed away, hospital, health worker, or another authorized agency.

c. The letter of proof as heirs can be in the form of:

1) Testament of the testator;

2) Court decision;

3) Decision from the judge/ chairman of the court;

4) For Indonesian citizens (indigenous people), a certificate of heirs is made by heirs witnessed by 2 (two) witnesses and confirmed by the Village Head and District Chief where the testator lived when he/ she passed away;

5) For Indonesian citizens of Chinese descent, a certificate of heirs is made by a notary;

6) For other Indonesian citizens of foreign eastern descent, a certificate of heirs is made by the Heritage Office.

d. A written power of attorney from the heirs if the person who submits the application for registration of transfer of rights is not the heir concerned.

e. Proof of the identity of the heirs.

2. If at the time of the application of transfer registration there is a court decision or determination of the chief judge of the court or inheritance deed as meant in Article 42 paragraph (4) Government Regulation No. 24 of 1997, the decision/ stipulation or deed is also attached to the application as referred to in paragraph (1)

3. The deed regarding the distribution of inheritance as referred to in paragraph (2) can be made in the form of a private deed by all heirs witnessed by 2 witnesses or in the form of a notarial deed.

4. If the heirs are more than 1 (one) person and there is no inheritance distribution, the registration of transfer of rights is carried out to the heirs as joint ownership and further distribution of rights can be carried out in accordance with Article 51 of Government Regulation No. 24 of 1997.

5. If the heirs are more than 1 (one) person and at the time of registration of the transfer of rights are accompanied by an inheritance deed containing information that the rights in estate falls to 1 (one) recipient of inheritance, the recording of transfer of rights is carried out to the recipient of the inheritance concerned based on the inheritance deed.

6. Recording of registration of transfer of rights as referred to in this Article in the lists of land registration is performed as mentioned in Article 105.

Recording of transfer of rights is regulated in Article 105 of the Regulation of the Minister of Agrarian Affairs/ Head of the National Land Agency No. 3 of 1997 as follows:

a. Recording of transfer of rights in the land book, certificate and other list is carried out as follows:

1) The name of the old right holder in the land book is crossed out with black ink and it is affixed with the initial head of the land office or the appointed official.

2) The name or names of the new rights holders are written on the pages and columns in the land book with the date of recording and the amount of the portion of each right holder in terms of the number of recipients of several people's rights and the determination of the 
amount of inheritance. After it is determined, it is then signed by the head of the land office or the appointed official and given the official stamp by the Land Office.

3) What is mentioned in points 1 and 2 is also implemented in the certificate of rights in question and other public lists that contain the name of the old right holder.

4) Other rights and identity numbers, from the transferred land, are crossed out from the list of names of the old rights holders and the rights and identity numbers are written on the list of names of right-holders.

b. If the new rights holders are more than 1 (one) person and the right is jointly owned, then, it must make a list of names for each rights holder and under the rights in the estate number are given a line in black ink.

c. If the transfer of rights is only about a portion of a rights in estate so that the rights in estate are jointly owned by the old rights holders and new rights holders, then the registration is carried out by writing down the number of the old rights holders behind their names and writing the names of new rights holders obtained on the provided page of changes.

d. The transferred certificate of rights is submitted to the new rights holder or the attorney.

Article 106 Regulation of the Minister of Agrarian Affairs/ Head of the National Land Agency No. 3 of 1997 states that in the case of the transferring rights in estate that has not been registered, the Conveyancer deed concerned shall be used as evidence in the first registration of the right on behalf of the last right holder in accordance with the provisions in Chapter III of this rule.

As described above, the problem is in terms of proof as heirs. Proof of heirs can be a testament of the testator, a court decision, the decision of a Chief Judge of the Court, or a certificate of heirs based on population classification. Based on interviews with respondents, when they want to transfer the rights in freehold estate through inheritance at the Padang National Land Agency office, they are required to make a certificate of heirs confirmed by the Village Head and District Chief. Without attaching the certificate of certification, the transfer of rights in freehold estate cannot be processed by the Padang National Land Agency. ${ }^{11}$

Meanwhile, as referred to in Article 111 paragraph (1) letter c Regulation of the Minister of Agrarian Affairs/ Head of the National Land Agency No. 3 of 1997 concerning Implementation Provisions of Government Regulation No. 24 of 1997 concerning Land Registration, a letter of proof as an heir is governed alternatively because of the phrase "or" in the rule. Alternative arrangements mean that it is enough to include one of the testaments of the testator, court decision, determination of the Chief Judge of the Court, or certificate of heirs based on population classification which is fulfilled by the applicant who transfers the rights in freehold estate through inheritance. So, the request should be further processed by the National Land Agency Office of Padang City. However, in practice, each applicant is required to make a certificate of heirs for proof that they are the heirs.

Certificate of heirs is distinguished based on population classification so that those who make certificate of heirs are also different. Indonesia has enacted various civil laws which include European (Western) Civil Law, Foreign East Civil Law, and Customary Civil Law (Customary Law) which all of them apply officially to the population groups in Indonesia. ${ }^{12}$ As the object of this research, it was conducted in Padang Utara District. Thus, it belongs to the category of certificate of heirs for Indonesian citizens of the native population, i.e. a certificate of heirs made by the heirs witnessed by 2 (two) witnesses and confirmed by the Village Head and District Chief at the living place of the testator when he/ she passed away.

\footnotetext{
${ }^{11}$ The results of the interview with Ms. X1 on Saturday, February 10, 2018 around 2:30 p.m. West Indonesia Time at her house dan interview with Ms. Y1 on Friday, February 16, 2018 around 5:00 p.m. West Indonesia Time at her house.

${ }^{12}$ C.S.T., Kansil, 2007, Op. Cit.
} 
Based on interviews with respondents, the role of the District Chief in the process of transferring rights in freehold estate through inheritance is only to sign a certificate of heirs made by heirs as one of the conditions for transferring rights in freehold estate through inheritance at the Land Agency Office of Padang City. The requirement is that the applicant attach the requirements requested by the District. The certificate of heirs made in the District are as follows: ${ }^{13}$

1. Certificate of heirs related to the transfer of rights in freehold estate divided into 2 (two) as follows:

a. Certificate of heirs for the transfer of rights in freehold estate which includes livelihoods.

b. Certificate of heirs related to rights in communal (ulayat) land.

2. Certificate of heirs for other purposes such as heir deposit disbursement which is carried out by heirs.

Certificate of heirs for Indonesian citizens (indigenous people) is divided into 2 (two), i.e. inheritance of freehold estate and hereditary property. The hereditary property is clearly based on the inheritance system of Customary Law which requires a family lineage to prove it. However, in the certificate of heirs for inheritance of freehold estate, the letter does not explain the object of research on the legal system of inheritance whether to use the Islamic inheritance law or the customary inheritance law.

However, based on the difference between communal (ulayat) land and freehold estate, communal (ulayat) land includes high hereditary property that imposes customary law. Inheritance, according to customary civil law is based on equality; i.e. the right to be treated equally by their parents in continuing and carrying out their property and family. In addition to the basic equality of rights, inheritance customary law also laid the line of descent in the process of carrying out the distribution of inheritance carried out in harmony with regard to the special conditions of each heir. ${ }^{14}$ Meanwhile, freehold estate includes low income or hereditary property that enforces the legal provisions of Islamic inheritance because the assets are obtained from the main family's livelihood during the household life of the main family.

Article 49 paragraph (1) Law No. 30 of 2014 concerning Government Administration states that government officials in accordance with their authorities must prepare and implement general guidelines for operational standard decision-making procedures. In the event that Village Head and District Chief reinforces the certificate of heirs, then, in the process of strengthening the certificate of heirs Village Head and District Chief must go through procedures that have been determined based on the authority set out in the applicable legislation.

The Legal Force of the Certificate of Heirs as the Basis for Transferring Rights in Freehold Estate through Inheritance in Padang Utara District

The legal force of certificate of heirs as the basis for transferring rights in freehold estate through inheritance is related to proof because certificate of heirs is a proof of inheritance as stipulated in Article 42 paragraph (1) Government Regulation No. 24 of 1997 concerning Land Registration which states that: registration of transfer of rights through inheritance regarding land parcels of rights that have been registered and apartment unit rights as required according to the provisions referred to in Article 36 must be submitted by those who receive rights in land or freehold estate on the apartment unit in question as an

\footnotetext{
${ }^{13}$ Interview with the Head of Government Section of Padang Utara District (Lola M. Daniel), on Thursday 1 February 2018 at around 10:00 West Indonesia Time at the District Office of Padang Utara.

${ }^{14}$ Soerjono Soekanto, Op. Cit.
} 
inheritance to the Land Office, the certificate of rights in question, the death certificate of the person whose name is recorded as the holder of rights and a letter of proof as heir.

Certificate of heirs as the basis for transferring rights in freehold estate through inheritance includes written evidence. Proof by writing is performed with authentic deeds and writings, not deeds as stipulated in Article 1867 of the Civil Code. An authentic deed is a deed whose form is determined by the Law made by or in front of the general employees in power for that in the place where the deed is made as stipulated in Article 1868 of the Civil Code. An authentic deed gives the parties and their heirs or people who have their rights a perfect proof of what is contained in it as stipulated in Article 1870 of the Civil Code.

Article 165 of Herzien Inlandsch Reglement states that: "A valid letter (deed) is a letter made so by or before a general employee in power to make it, sufficient evidence for both parties and their heirs and all persons who obtain the right thereof concerning all matters mentioned in the letter and also what is contained in the letter as a valid notification; only if the informed person is directly related to the subject matter of the letter (deed)." R. Subekti stated that what is meant in Article 165 of the Herzien Inlandsch Reglement is an authentic deed which is a perfect proof. Authentic deeds provide parties including their heirs or people who get the rights of the parties that is perfect proof of what is contained in it. ${ }^{15}$

The presence or testimony of a public official against a piece of evidence can add to the strength of its proof which can be categorized as a formal element of a deed; i.e. concerning the formality of the deed, concerning the truth of what is seen, witnessed and heard by an official, as well as the truth of the statement or statement of the parties submitted before an authorized official. It is certainly not appropriate if the Village Head and District Chief are considered to be able to provide the formal element to the certificate of heirs because the Village Head and District Chief do not have the authority in question stipulated in a legislation.

Based on interviews conducted by the authors, the respondents stated that there were children from the heirs who were still alive but lived in the Jakarta area, i.e. X2 and X3. ${ }^{16}$ Thus, the certificate of heirs made by the heirs will cause legal problems in the future because it did not include the names of other heirs into the certificate of heirs even though the other heirs are still alive. This event is a form of weakness of certificate of heirs made by heirs strengthened by Village Head and District Chief as stipulated in Article 111 paragraph (1) letter c Regulation of the Minister of Agrarian Affairs/ Head of National Land Agency No. 3 of 1997 concerning Implementation Provisions of Government Regulation No. 24 of 1997 concerning Land Registration.

In the opinion of Philip M. Hadjon, legal protection for the people is a preventive and repressive government action. Preventive legal protection aims to prevent disputes. It directs the government's actions to be careful in making decisions based on discretion. In addition, repressive protection aims to resolve disputes, including its handling in the judiciary. ${ }^{17}$

If the claim occurs by another heir whose name is not included in the certificate of heirs, it has entered the repressive stage to resolve the dispute. Law should provide preventive protection in advance in order not to cause legal disputes in the future. Transfer of rights in freehold estate includes one's civil rights including material rights. In this case, the transfer occurs through inheritance which includes a legal event.

Certificate of heirs should be in the form of an authentic deed to provide legal protection to other parties who are heirs and are entitled to inheritance from the testator. The certificate of heirs for Indonesian citizens (indigenous people) is only made by the heirs, strengthened by the Village Head and District Chief. On the other hand, Village Head and District Chief and heirs lack knowledge about inheritance law. Certificate of heirs has not been regulated by law so that it does not have the power of perfect proof as well as authentic deeds. In practice, a certificate of heirs can be misused by heirs to not include the names of other heirs as happened in Padang Utara District. It becomes an urgency for the state

\footnotetext{
${ }^{15}$ R. Subekti, Law of Proof, Pradnya Paramita, Jakarta, 1978, page 27

${ }^{16}$ The results of the interview with Ms. X1 on Saturday, February 10, 2018 around 2:30 p.m. West Indonesia Time at her house.

${ }^{17}$ Phillipus M. Hadjon, 1987, Legal Protection for the Indonesian People, PT Bina Ilmu, Surabaya, page 29
} 
to regulate inheritance law comprehensively in the form of legal products in the form of laws. It includes regulating who has the authority to make a certificate of heirs as the basis for the transfer of rights in freehold estate through inheritance.

Comprehensive inheritance law regulation including regulation of authority that makes certificate of heirs is very necessary as a form of preventive legal action from the state in order to protect one's civil rights for rights in their material arising from inheritance. The law is not only forced (dwingen recht) which only contains administrative sanctions, civil sanctions, and/ or criminal sanctions when a legal entity has occurred. However, it also has the nature of regulating (aanvullend recht) every action in community life to prevent the occurrence of lawsuits, especially certificate of heirs relating to civil rights that will determine who are the heirs who are entitled to the asset's inheritance of the testator. For instance, regarding to what happened in North Padang District, there were names of other heirs who were not included in the certificate of heirs. It certainly opens up opportunities for disputes if the heirs whose names not included in the certificate of heirs file a lawsuit to the court.

If a certificate of heirs is made in the form of an authentic deed, it is certainly made in the form specified by the Law and made by or before the authorities. So, the making process is regulated in clear rules and made by/ or before the parties that have inheritance legal competence. Thus, it gives legal certainty to the certificate of heirs itself. Even so, the certificate of heirs made by the heirs strengthened by the Village Head and District Chief does not have the power of perfect proof as the authentic deed because the Village Head and District Chief do not have the authority to enforce certificate of heirs.

\section{Legal Certainty Related to the Heirs Listed in the Certificate of Heirs Strengthened by Village Head and District Chief}

Based on interviews with respondents, when applying for a request for transfer of rights in freehold estate through inheritance at the National Land Agency Office of Padang City, the applicant is asked to make a certificate of heirs confirmed by Village Head and District Chief as proof of heir and as one requirement that must be met. ${ }^{18}$ Article 42 of Government Regulation No. 24 of 1997 concerning Land Registration states that:

1. Paragraph (1): In the registration of transfer of rights through inheritance concerning land plots that have been registered and rights in units of flats as required according to the provisions referred to in Article 36, they must be submitted by those who receive units of rights in land or freehold estate the apartment in question as an inheritance to the Land Office, the certificate of rights concerned, the death certificate of the person whose name is recorded as the holder of the rights and a letter of proof as heirs.

2. Paragraph (2): If the land plot which is an inheritance has not been registered, it is also obligatory to submit documents as referred to in Article 39 paragraph (1) letter b.

3. Paragraph (3): If the recipient of the inheritance consists of one person, the registration of the transfer of rights shall be carried out to the person based on the letter of proof as the heirs as referred to in paragraph (1).

4. Paragraph (4): If the recipient of inheritance is more than one person and when the transfer of rights is registered it is accompanied by a deed of inheritance which contains information that the rights in land or freehold estate of a certain apartment unit falls to a recipient of certain inheritance, registration of transfer of the rights in freehold estate for the apartment unit is carried out to the recipient of the inheritance concerned based on the letter of proof as the heirs and the deed of inheritance distribution.

\footnotetext{
${ }^{18}$ The results of the interview with Ms. X1 on Saturday, February 10, 2018 around 2:30 p.m. West Indonesia Time at her house dan interview with Ms. Y1 on Friday, February 16, 2018 around 5:00 p.m. West Indonesia Time at her house.
} 
5. Paragraph (5): Inheritance in the form of rights in land or freehold estate for apartment units which according to the inheritance deed must be shared between several recipients of inheritance or when it was registered there was no inheritance deed, the transfer of the rights could be registered to the recipients of inheritance who are entitled as their joint rights based on the letter of proof as heirs and/ or the deed of inheritance distribution.

The making process of certificate of heirs is still based on population classification as regulated in Article 111 paragraph (1) letter c Regulation of the Minister of Agrarian Affairs/ Head of National Land Agency No. 3 of 1997 concerning Implementation Provisions of Government Regulation No. 24 of 1997 concerning Land Registration which explains that the letter of proof can be in the form of:

1) Testament of the testator;

2) Court decision;

3) Decision from the judge/ chairman of the court;

4) For Indonesian citizens (indigenous people), a certificate of heirs is made by heirs witnessed by 2 (two) witnesses and confirmed by the Village Head and District Chief where the testator lived when he/ she passed away;

5) For Indonesian citizens of Chinese descent, a certificate of heirs is made by a notary;

6) For other Indonesian citizens of foreign eastern descent, a certificate of heirs is made by the Heritage Office.

Based on interviews with respondents, when applying for a transfer of rights in freehold estate through inheritance at the National Land Agency Office of Padang City, the applicant is asked to make a certificate of heirs confirmed by the Village Head and District Chief for proof of inheritance as a requirement which must be met. ${ }^{19}$ The National Land Agency of Padang City requires each applicant to make a certificate of heirs. In fact, the letter of proof as heirs is not just a certificate of heirs like the above alternative provisions. The difference in the certificate of heirs is originated from the classification of the population in which Indonesian citizens (indigenous people) made their own certificate of heirs witnessed by 2 (two) witnesses and strengthened by the Village Head and District Chief. Then, the policy that the certificate of inheritance rights of Indonesian citizens of Chinese descent was made by a notary and other Indonesian citizens of Eastern Foreign descent made by the Heritage Center caused discrimination against Indonesian citizens in terms of equality in law. As stated in Article 27 paragraph (1) of the 1945 Constitution, it states that every citizen has the same position in law and government and is obliged to uphold the law and government without exception. Then Article 28 D paragraph (1) of the 1945 Constitution states that everyone has the right to recognition, guarantee, protection and fair legal certainty and equal treatment before the law.

Since it is proof of inheritance, the certificate of heirs greatly influences the distribution of inheritance to the heirs so that the truth regarding anyone who has the right to be an heir of the testator's inheritance is determined by a certificate of heirs. However, in practice, the certificate of heirs for Indonesian citizens (indigenous people) is very vulnerable to being misused by not including other heirs who are also entitled to inheritance from the testator. That is because the making of certificate of heirs for Indonesian citizens (indigenous people) is made by the heirs witnessed by 2 (two) witnesses and confirmed by the Village Head and District Chief. Lack of knowledge from the heirs may lead to negligence in the inclusion of the list of heirs in the certificate of heirs. In addition, Village Head and District Chief only conduct administrative verification based on supporting data attached by the heirs. For

\footnotetext{
${ }^{19}$ The results of the interview with Ms. X1 on Saturday, February 10, 2018 around 2:30 p.m. West Indonesia Time at her house
} 
such reasons, a question arises as to whether or not the certificate of heirs made by the heirs have guaranteed legal certainty; because, as proof of inheritance, the certificate of heirs must have strong evidentiary power and be made by the authorized party that has the capacity to guarantee the strength of proof of the certificate of heirs.

After author's careful reading, the author does not find that Village Head and District Chief are authorized to participate in strengthening and signing the certificate of heirs as stipulated in Article 111 paragraph (1) letter c 4th Regulation of the Minister of Agrarian Affairs/ Head of National Land Agency No. 3 of 1997 concerning Implementation Provisions of Government Regulation No. 24 of 1997 concerning Land Registration. Based on the theory of attributive authority, every authority of a state institution must be regulated by Law as stipulated in Article 12 (1) of Law No. 30 of 2014 concerning Government Administration as follows:

1. Government agencies and/ or officials obtain authority through attribution if:

a. it is regulated in the 1945 Constitution of the Republic of Indonesia and/ or other laws;

b. it is a new authority or the authority that previously does not exist; and

c. attribution is given to agencies and/ or government officials.

2. Regarding government agencies and/ or officials who obtain authority through attribution, the responsibility of the authority rests with the agencies and/ or government officials concerned.

3. The authority for attribution cannot be delegated unless it is regulated in the 1945 Constitution of the Republic of Indonesia and/ or other laws.

Based on the above provisions, Village Head and District Chief's authority is not found in terms of participating in strengthening certificate of heirs as stipulated in Article 111 paragraph (1) letter c 4th Regulation of the Minister of Agrarian Affairs/ Head of National Land Agency No. 3 of 1997 concerning Implementation Provisions of Government Regulation No. 24 of 1997 concerning Land Registration; i.e. for Indonesian citizens (indigenous people), certificate of heirs is made by heirs witnessed by 2 (two) witnesses and confirmed by the Village Head and District Chief where the testator lived and passed away. Regulation of the Minister of Agrarian Affairs/ Head of the National Land Agency No.3 of 1997 concerning Implementation Provisions of Government Regulation No. 24 of 1997 concerning Land Registration is also not a form of delegation of authority since it is not contained in any Law that Village Head and District Chief has the authority to participate and strengthen certificate of heirs because there is no regulation on comprehensive inheritance law.

Reviewing Law No. 24 of 2013 concerning Amendment to Law No. 23 of 2006 concerning Population Administration, it is also not found that the certificate of heirs is one type of population document as stipulated in Article 1 No. 8 of the Law of the Republic of Indonesia No. 24 of 2013 concerning Amendment to Law No. 23 of 2006 concerning Population Administration which states that population documents are official documents issued by Executing Agencies that have legal force as authentic evidence produced from population registration and civil registration services. When there is no authority of the Village Head and District Chief to participate in strengthening the certificate of heirs, is the certificate of heirs a discretion? Based on Article 1 No. 9 of the Law of the Republic of Indonesia No. 30 of 2014 concerning Government Administration, discretion is a decision and/ or action determined and/ or carried out by government officials to overcome concrete problems faced in the administration of government in terms of legislation that provides choices, does not regulate, is incomplete or unclear, and/ or contains government stagnation. Based on the definition of discretion, things related to Village Head and District Chief who strengthen certificate of heirs including discretion. However, based on Article 22 paragraph (1) of the Law of the Republic of Indonesia No. 30 of 2014 concerning Government Administration, discretion can only be carried out by authorized government officials. 
Authorized government officials are government officials who are authorized by the 1945 Constitution and/ or other Law. Although discretion aims to fill the legal vacuum, it cannot be used freely because it is limited by the authority of government officials themselves. As long as government officials have authority regulated by the 1945 Constitution and/ or other Law, but a problem requires a decision and/ or action from government officials who are not clearly and completely regulated, then discretion can be carried out.

Therefore, regarding the meaninglessness of Village Head and District Chief authority to participate in strengthening and signing a certificate of heirs, the certificate of heirs is only a letter that does not have perfect legal force. Whereas, certificate of heirs should be a proof of inheritance that is used for the transfer of rights in freehold estate through inheritance that determines who the heirs are entitled to material rights from the testator's inheritance. Thus, the involvement of Village Head and District Chief in strengthening the certificate of heirs does not provide legal certainty regarding the truth of the heirs listed therein. In addition, Village Head and District Chief do not have authority in positive law that applies to strengthen the certificate of heirs.

\section{Conclusions}

Based on the results of the research that the authors have been conducted, the authors draw the following conclusions:

1. The process of the transfer of rights in freehold estate through inheritance based on a certificate of heirs in Padang Utara District of Padang City can be misused by the heirs by not including the names of other legal heirs; therefore, other heirs whose names are not included in the certificate of heirs can file a claim against the certificate of heirs.

2. The legal strength of certificate of heirs, as the basis of the transfer of rights in freehold estate through inheritance in Padang Utara District, does not have perfect legal force because the Village Head and District Chief does not have the authority to strengthen the certificate of heirs.

The lack of legal certainty in the certificate of heirs strengthened by Village Head and District Chief as the basis for the transfer of rights in freehold estate through inheritance was caused by the Village Head and District Chief not having the authority to strengthen the certificate of heirs.

\section{References}

Amiruddin \& Zainal Asikin. (2004). Introduction to Legal Research Methods, Raja Grafindo Persada, Jakarta, page 133 .

Banakar, Reza, and Max Travers, eds. (2005). Theory and method in socio-legal research. Bloomsbury Publishing.

C.S.T., Kansil. (2007). Practice for Exams: Introduction to Indonesian Law, Sinar Grafika, Jakarta, page 18.

Chynoweth, Paul. (2008): "Legal research." Advanced research methods in the built environment: 28-38.

Gultomlawconsultant.com, Certificate of Heirs and Authorized Parties Who Can Publish it. 
McConville, Mike, ed. (2017). Research methods for law. Edinburgh University Press.

Phillipus M. Hadjon. (1987). Legal Protection for the Indonesian People, PT Bina Ilmu, Surabaya, page 29.

R. Subekti, Law of Proof, Pradnya Paramita, Jakarta. (1978). page 27.

Webley, Lisa. (2010). "Qualitative approaches to empirical legal research." The Oxford handbook of empirical legal research.: 926-950.

Internet

http://Irma devita.com, Description of Inheritance.

http://habibadjie.com, Equality in Evidence Making as Heirs.

\section{Copyrights}

Copyright for this article is retained by the author(s), with first publication rights granted to the journal. This is an open-access article distributed under the terms and conditions of the Creative Commons Attribution license (http://creativecommons.org/licenses/by/4.0/). 